\title{
Protein Nanocages for Delivery and Release of Luminescent Ruthenium (II) Polypyridyl Complexes
}

\author{
Xiao Li, ${ }^{\dagger}$ Yajie Zhang, ${ }^{\dagger}$ Hong Chen, ${ }^{\dagger},+$ Jian Sun ${ }^{\dagger}$ and Fude Feng ${ }^{*}{ }^{\dagger}$ \\ ${ }^{\dagger}$ Department of Polymer Science \& Engineering, School of Chemistry \& Chemical \\ Engineering, Nanjing University, Nanjing 210023, P. R. China \\ $\$$ Lab of Advanced Functional Materials, School of Environmental Science, \\ Nanjing Xiaozhuang University, Nanjing 210013, P. R. China
}

Email: fengfd@nju.edu.cn 


\section{Contents}

Experimental section

Figure S1.

Figure S2.

Table S1.

Figure S3.

Figure S4.

Figure S5.

Figure S6.

Figure S7.

Reference 


\section{Experimental Section.}

\section{Materials and methods}

All reagents were commercially available and used as supplied without further purification unless otherwise stated. Horse spleen ferritin and folic acid were purchased from Sigma Aldrich. $O$-phenylenediamine, N-hydroxy-sulfosuccinimide (NHS), dicyclohexylcarbodiimide (DCC) and $n$-octanol were purchased from J\&K Chemicals. Thioglycolic acid, $\mathrm{RuCl}_{3} \cdot \mathrm{xH}_{2} \mathrm{O}(38 \%-42 \%, \mathrm{Ru}$ basis), 2,2'-bipyridine, $\left[\mathrm{Ru}(\mathrm{bpy})_{3}\right] \mathrm{Cl}_{2} \cdot 6 \mathrm{H}_{2} \mathrm{O}$ (bpy $=2,2^{\prime}$-bipyridine), $\mathrm{NH}_{4} \mathrm{PF}_{6}$, phenanthroline (phen), $\left(\mathrm{NH}_{4}\right)_{2} \mathrm{Fe}\left(\mathrm{SO}_{4}\right)_{2}$, ferrozine, neocuproine hemihydrate, ammonium acetate and sodium ascorbate were all from Aladdin (Shanghai, China). 3-(4,5-dimethyl-2-thiazolyl)-2,5-diphenyl2-H-tetrazolium bromide (MTT) was bought from Biosharp. Uranyl acetate was supplied by Zhongjingkeyi Technology Co., Ltd. (Beijing, China). Fetal Bovine Serum (FBS) and Dulbecco's modified Eagle's medium (DMEM) were purchased from Biological Industries and KeyGen BioTech respectively. MCF-7 cells used in the research were obtained from American Type Culture Collection.

NMR spectra were recorded on a Bruker AMX 300 spectrophotometer with use of residual solvent or TMS as the internal reference. Circular dichroism (CD) spectra were recorded on Chirascan (Applied Photophysis, U.K.). Protein concentrations were measured on a multimode microplate reader (Infinite M200 Pro., Tecan, Switzerland) with bovine serum albumin (BSA) as the reference. Transmission electron microscopy (TEM) images and energy-dispersive X-ray spectra (EDX) were collected on JEM-2100 (JEOL, Ltd., Japan). Particle sizes and $\zeta$-potential values of Ru-NPs were measured on Zetasizer nanoseries (Nano zs90, Malvern Instruments Ltd., U.K.). Inductively coupled plasma optical emission spectra (ICP-OES) were collected by a Perkin 
Elmer Optima 3000DV series ICP-OES instrument. Ultraviolet-visible (UV-vis) spectra and fluorescent emission spectra were taken on a P-General UV-Vis or Shimadzu UV-2600 spectrophotometer and Hitachi F-7000 fluorimeter respectively. Fluorescence images were taken on an inverted fluorescence microscope (Nikon TE2000-U, Japan) or confocal laser scanning microscope (LSM 710, Zeiss, Germany) equipped with a combination of excitation and emission filters for each dye.

\section{Synthesis of compounds $\left[\mathrm{Ru}(\mathrm{bpy})_{3}\right]\left(\mathrm{PF}_{6}\right)_{2},\left[\mathrm{Ru}(\mathrm{bpy})_{2} \mathrm{dppz}\right]\left(\mathrm{PF}_{6}\right)_{2}$ and $\left[\mathrm{Ru}(\mathrm{phen})_{2} \mathrm{dppz}\right]\left(\mathrm{PF}_{6}\right)_{2}$}

Ruthenium complexes: $\left[\mathrm{Ru}(\mathrm{bpy})_{3}\right]\left(\mathrm{PF}_{6}\right)_{2}(\mathbf{R u 1}),\left[\mathrm{Ru}(\mathrm{bpy})_{2} \mathrm{dppz}\right]\left(\mathrm{PF}_{6}\right)_{2}\left(\mathrm{bpy}=2,2^{\prime}\right.$-bipyridine, dppz $=$ dipyrido[3,2-a:2',3'-c]phenazine) $(\mathbf{R u 2})$ and $\left[\mathrm{Ru}(\text { phen })_{2} \mathrm{dppz}\right]\left(\mathrm{PF}_{6}\right)_{2} \quad($ phen $=$ phenanthroline) (Ru3) were synthesized according to published procedures. ${ }^{1}$

Synthesis of Ru1: The solution of $\left[\mathrm{Ru}(\mathrm{bpy})_{3}\right] \mathrm{Cl}_{2} \cdot 6 \mathrm{H}_{2} \mathrm{O}(0.910 \mathrm{~g}, 1.16 \mathrm{mmol})$ in de-ionized water $(20 \mathrm{~mL})$ was added dropwise to a saturated aqueous $\mathrm{NH}_{4} \mathrm{PF}_{6}$ solution $(20 \mathrm{~mL})$. The obtained orange product was kept under stirring for $2 \mathrm{~h}$. Orange microcrystalline $(0.962 \mathrm{~g}, 92 \%)$ was obtained after filtration, cooled water washing, diethylether reprecipitation and vacuum drying.

Synthesis of dppz: A mixture solution of concentrated $\mathrm{H}_{2} \mathrm{SO}_{4}$ (aq, $20 \mathrm{~mL}$ ) and $\mathrm{HNO}_{3}$ (aq, 10 $\mathrm{mL})$ was added dropwise into the mixture of phen $(2.00 \mathrm{~g}, 10.0 \mathrm{mmol})$ and $\mathrm{KBr}(2.00 \mathrm{~g})$. Then, the solution was refluxed for $3 \mathrm{~h}$ at $150{ }^{\circ} \mathrm{C}$. The resulted solution was added to the cooled de-ionized water $\left(4^{\circ} \mathrm{C}, 250 \mathrm{~mL}\right)$ and $10 \mathrm{M} \mathrm{NaOH}(\mathrm{aq}, 80 \mathrm{~mL})$ was subsequently added dropwise to neutralize the solution. After extraction with $\mathrm{CHCl}_{3}(3 \times 100 \mathrm{~mL})$, de-ionized water $(50 \mathrm{~mL})$ was added, then the organic phase was collected, dried over anhydrous $\mathrm{Na}_{2} \mathrm{SO}_{4}$ and concentrated under vacuum to afford phenO 2 as a light yellow powder $(1.80 \mathrm{~g}, 85 \%)$. $\mathrm{PhenO}_{2}(0.315 \mathrm{~g}, 1.5 \mathrm{mmol}, 1$ eq.) and $o$-phenylenediamine $(0.227 \mathrm{~g}, 2.1 \mathrm{mmol}, 1.4$ eq. $)$ were dissolved in anhydrous ethanol 
and refluxed for $10 \mathrm{~min}$. Compound dppz was recrystallized from cooled water, and obtained as light yellow crystals $(0.390 \mathrm{~g}, 91 \%)$.

Synthesis of $\left[\mathrm{Ru}(\text { bpy })_{2} d p p z\right]\left(\mathrm{PF}_{6}\right)_{2}$ : A mixture solution of $\mathrm{RuCl}_{3} \cdot \mathrm{xH}_{2} \mathrm{O}(38 \%-42 \%$, Ru basis $)$ (0. $253 \mathrm{~g}, 0.99 \mathrm{mmol}, 1$ eq.) and bpy (0.312 g, $2.00 \mathrm{mmol}, 2.02$ eq.) in N,N-dimethyl formamide $\left(20 \mathrm{~mL}\right.$ ) was refluxed for $4 \mathrm{~h}$ at $150{ }^{\circ} \mathrm{C}$. After removal of solvent under vacuum, the residue was purified by recrystallization from acetone and dried under vacuum. The crystals were mixed with $\mathrm{LiCl}(5 \mathrm{~g})$ and refluxed for $1 \mathrm{~h}$ in a solution of water and ethanol $(140 \mathrm{~mL}, v / v=1)$. After recrystallization from cooled water, $\left[\mathrm{Ru}(\mathrm{bpy})_{2} \mathrm{Cl}_{2}\right]$ was obtained as black crystals $(0.319 \mathrm{~g}, 66 \%)$. A solution of $\left[\mathrm{Ru}(\mathrm{bpy})_{2} \mathrm{Cl}_{2}\right](0.145 \mathrm{~g}, 0.30 \mathrm{mmol}, 1$ eq.) and dppz (0.094 g, $0.33 \mathrm{mmol}, 1.10$ eq.) in $\mathrm{N}, \mathrm{N}$-dimethyl formamide $(20 \mathrm{~mL})$ was refluxed for $4 \mathrm{~h}$ at $150{ }^{\circ} \mathrm{C}$ under a nitrogen atmosphere. Then the red solution was cooled to room temperature, a dark red precipitate was obtained by addition of a saturated aqueous $\mathrm{NH}_{4} \mathrm{PF}_{6}$ solution. Yield: $65 \%$. ${ }^{1} \mathrm{H}$ NMR $\left(300 \mathrm{MHz}\right.$, acetone- $d_{6}$, $298 \mathrm{~K}) \delta(\mathrm{ppm}): 9.78(\mathrm{dd}, J=8.2,1.3 \mathrm{~Hz}, 2 \mathrm{H}, \operatorname{Ar} H), 8.94-8.81(\mathrm{~m}, 4 \mathrm{H}, \operatorname{Ar} H), 8.57$ (dd, $J=5.4$, $1.3 \mathrm{~Hz}, 2 \mathrm{H}, \operatorname{Ar} H), 8.52(\mathrm{dd}, J=8.2,5.4 \mathrm{~Hz}, 2 \mathrm{H}, \operatorname{Ar} H) .8 .33-8.26(\mathrm{~m}, 2 \mathrm{H}, \operatorname{Ar} H), 8.25-8.15(\mathrm{~m}, 6 \mathrm{H}$, $\operatorname{Ar} H), 8.15-8.07$ (m, 4H, ArH), 7.72-7.60 (m, 2H, ArH), 7.48-7.36 (m, 2H, ArH).

Synthesis of $\left[R u(p h e n)_{2} d p p z\right]\left(P F_{6}\right)_{2}$ : The complex was synthesized by the similar procedures described above for the synthesis of $\left[\mathrm{Ru}(\mathrm{bpy})_{2} \mathrm{dppz}\right]\left(\mathrm{PF}_{6}\right)_{2}$ except that phen was used in place of bpy. Yield: $62 \% .{ }^{1} \mathrm{H}$ NMR (300 MHz, DMSO- $\left.d_{6}, 298 \mathrm{~K}\right) \delta(\mathrm{ppm}): 9.60(\mathrm{dd}, J=8.2 \mathrm{~Hz}, 1.1 \mathrm{~Hz}$, 2H, ArH), 8.81-8.74 (m, 4H, ArH), 8.56-8.50 (m, 2H, ArH), 8.39 (s, 4H, ArH), $8.26(\mathrm{dd}, J=$ 4.2,1.0 Hz, 2H, $\operatorname{Ar} H), 8.23-8.17(\mathrm{~m}, 4 \mathrm{H}, \operatorname{Ar} H), 8.04(\mathrm{~d}, J=5.2,1.0 \mathrm{~Hz}, 2 \mathrm{H}, \operatorname{Ar} H), 7.89(\mathrm{dd}, J=8.2$, $5.4 \mathrm{~Hz}, 2 \mathrm{H}, \mathrm{Ar} H), 7.82-7.72(\mathrm{~m}, 4 \mathrm{H}, \operatorname{Ar} H)$.

\section{Lipophilicity $(\log$ P) determination}


The partition coefficients (log $\mathrm{P})$ were measured according to the reported procedure with minor modification. ${ }^{2}$ Aqueous solution of ruthenium complex with counter ion of $\mathrm{Cl}$ or $\mathrm{PF}_{6}$ was prepared at $50 \mu \mathrm{M}$. Then an equal volume of $n$-octanol was added. The two phases were mutually saturated by shaking $12 \mathrm{~h}$ at $25{ }^{\circ} \mathrm{C}$ and allowed to separate by centrifugation. The concentration of the metal complex in each phase was determined on a UV-Vis spectrophotometer at maximum MLCT absorption wavelength.

\section{De-ironization of ferritin and encapsulation of Ru complexes into apoferritin}

The as-received horse spleen ferritin solution was diluted to $5 \mathrm{mg} / \mathrm{mL}$ with Tris-HCl buffer ( $\mathrm{pH}$ 7.4). The protein content was determined by bicinchonininc acid (BCA) protein assay kit (Biosharp). The $\mathrm{pH}$ of ferritin solution was adjusted to 5 by $\mathrm{HCl}$ (aq., $0.1 \mathrm{M}$ ). A clear solution (10 $\mathrm{mL})$ was obtained apoferritiner thioglycolic acid $(100 \mu \mathrm{L})$ was added and allowed to stand still at $4^{\circ} \mathrm{C}$ for $16 \mathrm{~h}^{3}$ Then, an saturated aqueous $2,2^{\prime}$-bipyridine solution $(2 \mathrm{~mL})$ was added and the mixture was dialyzed against Tris- $\mathrm{HCl}$ buffer $(\mathrm{pH}=7.4)$ for 2 days with a molecular weight cutoff of $7000 \mathrm{Da}$. A clear colorless apo horse spleen ferritin (apoferritin) was obtained.

Loading of Ru complexes into apoferritin cavities was carried out in the presence of organic solvents to prevent protein aggregation in the course of Ru-NPs preparation and purification. Apoferritin $(0.5 \mathrm{mg} / \mathrm{mL}, 10 \mathrm{~mL}, 1$ eq.) and the $\mathrm{pH}$ was adjusted slowly to 2 and then the $\mathbf{R u} 2$ and Ru3 solution (50 mM in acetonitrile, $45 \mu \mathrm{L}, 200$ eq.) was added in. In comparison, apoferritin simply mixed with $\mathbf{R u} 2$ and $\mathbf{R u} \mathbf{3}$ without $\mathrm{pH}$ adjustment also applied. The mixture was stirred for $1 \mathrm{~h}$ at room temperature. Then, the $\mathrm{pH}$ was elevated to 9 by $\mathrm{NaOH}$ (aq., $0.1 \mathrm{M}$ ), the solution was allowed to stand still at $4^{\circ} \mathrm{C}$ for $2 \mathrm{~h}$. The solution was carefully dialyzed against $0 \%$ or $10 \%$ acetonitrile in Tris- $\mathrm{HCl}$ buffer $(\mathrm{pH}=9)$ for $12 \mathrm{~h}$ and subsequent Tris- $\mathrm{HCl}$ buffer $(\mathrm{pH}=9)$ for 
additional $48 \mathrm{~h}$ at $4{ }^{\circ} \mathrm{C}$ with a molecular weight cutoff of $7000 \mathrm{Da}$. In the course of dialysis in the absence of acetonitrile, significant precipitation of protein aggregates induced by $\mathbf{R u} \mathbf{2}$ or Ru3 occurred.

\section{Metal content analysis}

Fe content analysis ${ }^{4}$ : Standard solutions used to generate a calibration curve were prepared from $\left(\mathrm{NH}_{4}\right)_{2} \mathrm{Fe}\left(\mathrm{SO}_{4}\right)_{2}$ (Metal basis). Calibration concentrations ranged from 0.05 to $3.2 \mu \mathrm{g} / \mathrm{mL}$ metal, and 8 points altogether were used to construct each calibration curve. $\mathrm{KMnO}_{4}(17 \mathrm{mg})$ was added to $\mathrm{HCl}$ solution $(0.75 \mathrm{M}, 6 \mathrm{~mL})$ to form a protein and $\mathrm{Fe}$ oxidizing solution. Iron detection solution was prepared as a mixture of ferrozine $(6.5 \mathrm{mM})$, neocuproine hemihydrate $(6.5 \mathrm{mM})$, ammonium acetate $(1.0 \mathrm{mM})$ and sodium ascorbate $(2.5 \mathrm{mM})$ in de-ionized water. The mixture of apoferritin $(120 \mu \mathrm{L})$ and oxidizing solution $(200 \mu \mathrm{L})$ was shaken in a MixStar (Thermo Fisher Scientific) at $60{ }^{\circ} \mathrm{C}$ for $2 \mathrm{~h}$. Then, iron detection solution $(200 \mu \mathrm{L})$ was added and shaken at room temperature for $30 \mathrm{~min}$. Absorbance at $562 \mathrm{~nm}$ were measured on the microplate reader. The results indicated there were less than $2 \mathrm{Fe}$ atoms per apoferritin cage.

$R u$ content analysis: 1) ICP-OES based method: Standard solutions (5 p.p.m.) used were prepared from $\mathrm{RuCl}_{3} \cdot \mathrm{xH}_{2} \mathrm{O}(38 \%-42 \%$, Ru basis) in $6 \mathrm{M} \mathrm{HCl}$. Ru-NPs $(5 \mathrm{~mL})$ were digested with aqua regia and $\mathrm{H}_{2} \mathrm{O}_{2}$ at $150{ }^{\circ} \mathrm{C}$ for three times, and finally the volume of mixture was fixed to 5 mL. ICP-OES analysis was performed on a PerkinElmer Optima 3000 DV ICP-OES spectrometer. 2) UV-Vis based method: the UV-Vis spectra of Ru-NPs ( $3 \mathrm{~mL}, 0.5 \mathrm{mg} \cdot \mathrm{mL}^{-1}$ ) were examined. The concentrations of Ru complexes in Ru-NPs solution are obtained according to the published molar extinction coefficient of Ru complexes at $440 \sim 450 \mathrm{~nm} .{ }^{1,5-6}$

\section{Characterization of Ru-NPs}


Transmission electron microscopy (TEM): TEM of apoferritin and Ru-NPs was carried out with uranyl acetate as negative staining reagent. Drops of apoferritin or Ru-NPs (protein concentration of $0.5 \mathrm{mg} / \mathrm{mL}$ determined by BCA assay) were adsorbed on 400-mesh carbon-coated copper grids (Electron Microscopy Services). After 3 min, excess fluid was removed from the edge of grid with filter paper. The grid was stained with $1 \%$ pre-filtered uranyl acetate solution for $3 \mathrm{~min}$, blotted with filter paper, immersed into ethanol in order to remove excessive uranyl acetate, and air dried at room temperature before being subjected to TEM analysis.

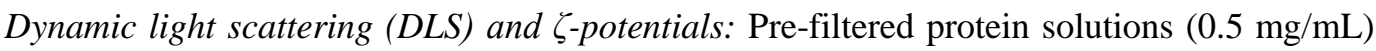
in $20 \mathrm{mM}$ Tris- $\mathrm{HCl}$ buffer $(\mathrm{pH}=7.4)$ were subjected to dynamic light scattering in a disposable poly(styrene) cell (Malvern Instruments Ltd., U.K.) pre-equilibrated for $10 \sim 20 \mathrm{~min}$ at $298 \mathrm{~K}$. The scanning cycled for $3 \times 30$ times. Protein solutions $(0.5 \mathrm{mg} / \mathrm{mL})$ in $1.0 \mathrm{mM}$ aq. $\mathrm{KCl}$ were subjected to $\zeta$-potential measurements in a disposable folded capillary cell (DTS 1070, Malvern Instruments Ltd., U.K.) pre-equilibrated at 298 K. The $\zeta$-potential values were calculated from the obtained electrophoretic mobility by applying the Smoluchowski equation.

Circular dichroism (CD): CD spectra were recorded on Chirascan (applied photophysis, U.K.) in the far-ultraviolet wavelength range of $190 \sim 260 \mathrm{~nm}$ in a quartz cell $(0.1 \mathrm{~cm})$ using following parameters: bandwidth, $1 \mathrm{~nm}$; step resolution, $0.1 \mathrm{~nm}$; scan speed, $10 \mathrm{~nm} \mathrm{~min}{ }^{-1}$; and response time, $1 \mathrm{~s}$. The data of each spectrum were the average of three scans. All samples were at the same protein concentration $(0.5 \mathrm{mg} / \mathrm{mL}, 20 \mathrm{mM}$ Tris- $\mathrm{HCl}, \mathrm{pH}=9.4)$.

Quantum yields: UV-vis spectra were taken as described above. With the $450 \mathrm{~nm}$ excitation, fluorescent emission spectra $(550 \sim 750 \mathrm{~nm})$ were taken on Hitachi F-7000 fluorimeter (EM Slit 5 
nm, EX Slit 5 nm, FMT 600 V). Ru-NPs were measured in Tris-HCl buffer $(20 \mathrm{mM}, \mathrm{pH}=7.4)$ at $298 \mathrm{~K}$ and the standard emission quantum yields were determined using $\left[\mathrm{Ru}(\mathrm{bpy})_{3}\right] \mathrm{Cl}_{2}$ in air-equilibrated water $\left(\Phi_{\text {lum }}=0.028\right)^{7}$ and roughly calculated based on the following equation:

$$
\Phi_{u n k}=\Phi_{s t d}\left(\frac{A_{s t d}}{I_{s t d}}\right)\left(\frac{I_{u n k}}{A_{u n k}}\right)\left(\frac{\eta_{u n k}}{\eta_{s t d}}\right)^{2}
$$

Where $\Phi$ is quantum yield, $A$ is absorption, $I$ is luminescence intensity, $\eta$ is refractive index of solvent while unk and std are represented as unknown and standard substance respectively.

\section{Ru complexes release profiles}

After gradient dilution of Ru loaded proteins with Ru concentrations ranged from 1.56 to 25 $\mu \mathrm{M}$, the fluorescence intensities at $610 \mathrm{~nm}\left(\lambda_{\mathrm{ex}}=450 \mathrm{~nm}\right)$ of Ru2-NP and Ru3-NP $(200 \mu \mathrm{L})$ in 96-well plates were recorded on a multimode microplate reader to construct each calibration curve of $\mathrm{Ru}$ complex (Figure S5). For Ru release assays, Ru2-NP and Ru3-NP were dialyzed in Tris- $\mathrm{HCl}$ buffer $(\mathrm{pH}=7.4)$ at $37^{\circ} \mathrm{C}$, and a volume of $500 \mu \mathrm{L}$ of the protein solution was taken out at certain time intervals to allow for measurements of fluorescence intensity according to calibration curve. A plot of $I_{0} / I$ as a function of time was made obtain $t_{1 / 2}$.

\section{Functionalization of Ru-NPs with Folic Acid}

Folic acid active ester (FA-NHS) was synthesized according to the reported procedure. ${ }^{8}$ Proteins $(0.5 \mathrm{mg} / \mathrm{mL}, 1$ eq.) were mixed with FA-NHS (5.4 mg/mL, 200 eq.) in PBS buffer and incubated over a period of $24 \mathrm{~h}$ at $4{ }^{\circ} \mathrm{C}$. Folate-conjugated proteins were purified on chilled PD-10 desalting columns (GE, USA).

\section{Imaging of MCF-7 cells by Ru-NPs}

MCF-7 cells were seeded in 4-well glass-bottomed plates $(\Phi=24 \mathrm{~mm})$ at a density of $8 \times 10^{4}$ 
cells per well for CLSM in complete DMEM containing $10 \%$ fetal bovine serum, supplemented with $50 \mathrm{U} \cdot \mathrm{mL}^{-1}$ penicillin and $50 \mathrm{U} \cdot \mathrm{mL}^{-1}$ streptomycin, and cultured in $5 \% \mathrm{CO}_{2}$ at $37^{\circ} \mathrm{C}$. After 24 h, the cells were incubated with Ru complexes, Ru-NPs and FA-Ru-NPs respectively for additional $24 \mathrm{~h}$ or $36 \mathrm{~h}$; or the cells were pre-incubated with $500 \mu \mathrm{M}$ folic acid for $4 \mathrm{~h}$, followed by incubation with Ru2-NP or Ru3-NP for additional 24 h. After multiple washes with PBS buffer, the cells were analyzed by confocal microscopy. Ru complexes were excited at $488 \mathrm{~nm}$ and emission signal was collected at $550 \sim 750 \mathrm{~nm}$ ranges. Confocal fluorescence imaging studies were performed with a Zeiss laser scanning microscope 710 with a 40× water objective lens, using Zen 2008 software (Carl Zeiss) for data analysis.

\section{MTT assay}

MCF-7 cells were seeded in 96-well plates in complete DMEM containing 10\% fetal bovine serum, supplemented with $50 \mathrm{U} \cdot \mathrm{mL}^{-1}$ penicillin and $50 \mathrm{U} \cdot \mathrm{mL}^{-1}$ streptomycin, and cultured in $5 \%$ $\mathrm{CO}_{2}$ for $24 \mathrm{~h}$ at $37^{\circ} \mathrm{C}$. Then the cells were treated with 1) apoferritin, apoferritin-MeCN (apoferritin re-assembled and dialyzed in the presence of $10 \%$ acetonitrile in Tris- $\mathrm{HCl}$ buffer $(\mathrm{pH}$ = 9). Acetonitrile was removed by additional dialysis against Tris- $\mathrm{HCl}$ buffer), FA-apoferritin (protein concentration of $0.5,1$ and $2 \mu \mathrm{M}$ ), or 2) Ru1, Ru2 and Ru3 (Ru concentration: 0.5, 1, 2.5, 5, 12.5, 25, 37.5 and $50 \mu \mathrm{M}$ ), or 3) Ru1, Ru1-NP, FA-Ru1-NP, Ru2, Ru2-NP, FA-Ru2-NP, Ru3, Ru3-NP and FA-Ru3-NP (Ru concentration: 0 or $10 \mu \mathrm{M}$ ) for $24 \mathrm{~h}$. MCF-7 cells were washed with PBS for three times followed by incubation with MTT $(0.5 \mathrm{mg} / \mathrm{mL}$ in complete culture medium) for $4 \mathrm{~h}$ in culture condition. The medium was carefully removed and the formed formazan was washed with PBS buffer. Then DMSO (200 $\mu \mathrm{L})$ was added to dissolve formazan. The OD values at $490 \mathrm{~nm}$ and $720 \mathrm{~nm}$ were collected on a multimode microplate reader. 
(a)

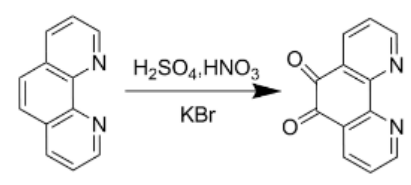

phen

phenO $\mathrm{O}_{2}$

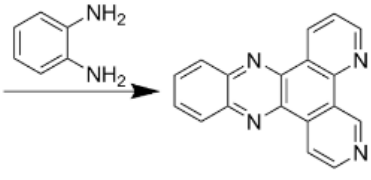

dppz

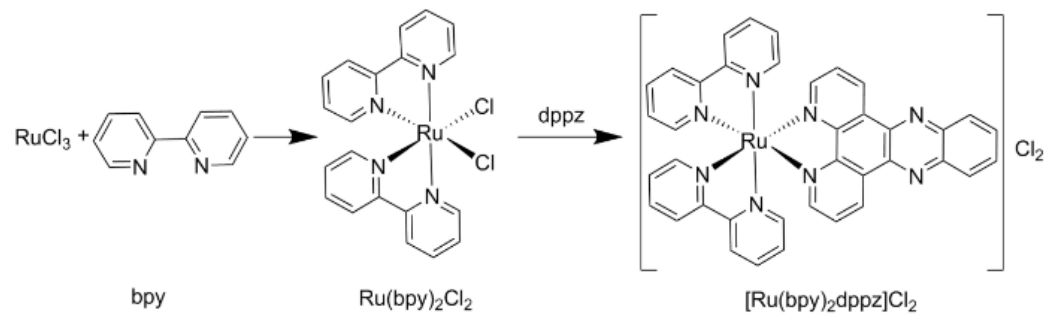

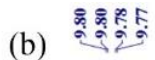

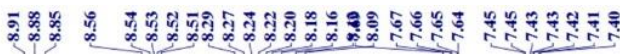
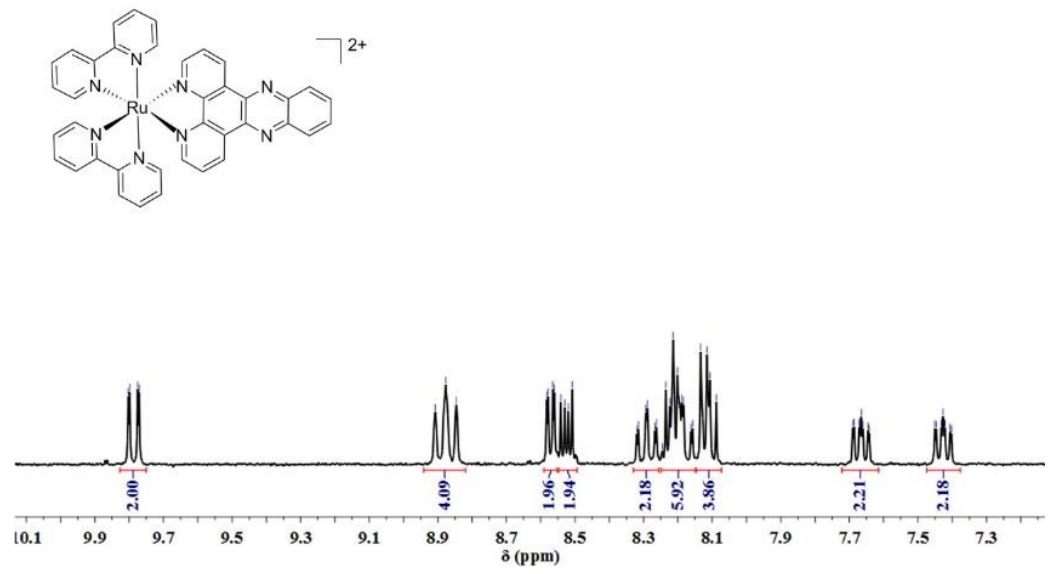

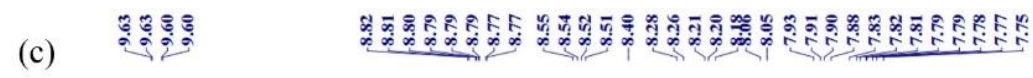
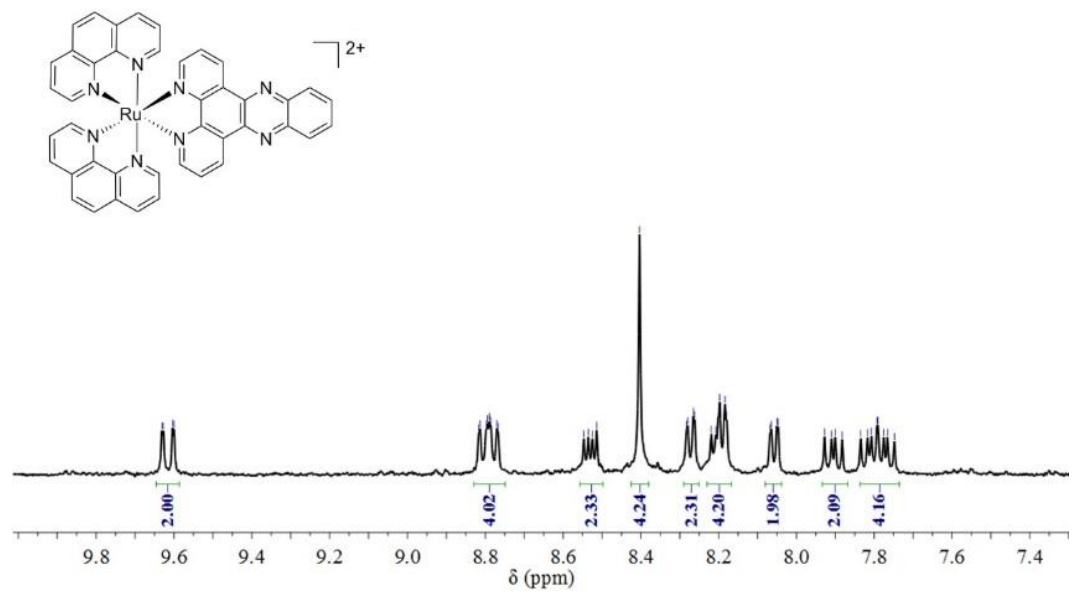

Figure S1. The synthesis route of $\left[\mathrm{Ru}(\mathrm{bpy})_{2} \mathrm{dppz}\right] \mathrm{Cl}_{2}$ (a) and ${ }^{1} \mathrm{H}$ NMR spectra of $\left[\mathrm{Ru}(\text { phen })_{2} \mathrm{dppz}\right]\left(\mathrm{PF}_{6}\right)_{2}\left(300 \mathrm{MHz}\right.$, acetone- $\left.d_{6}, 298 \mathrm{~K}\right)(\mathrm{b})$ and $\left[\mathrm{Ru}(\text { phen })_{2} \mathrm{dppz}\right]\left(\mathrm{PF}_{6}\right)_{2}(300 \mathrm{MHz}$, DMSO-d6, 298 K) (c). 
(a)

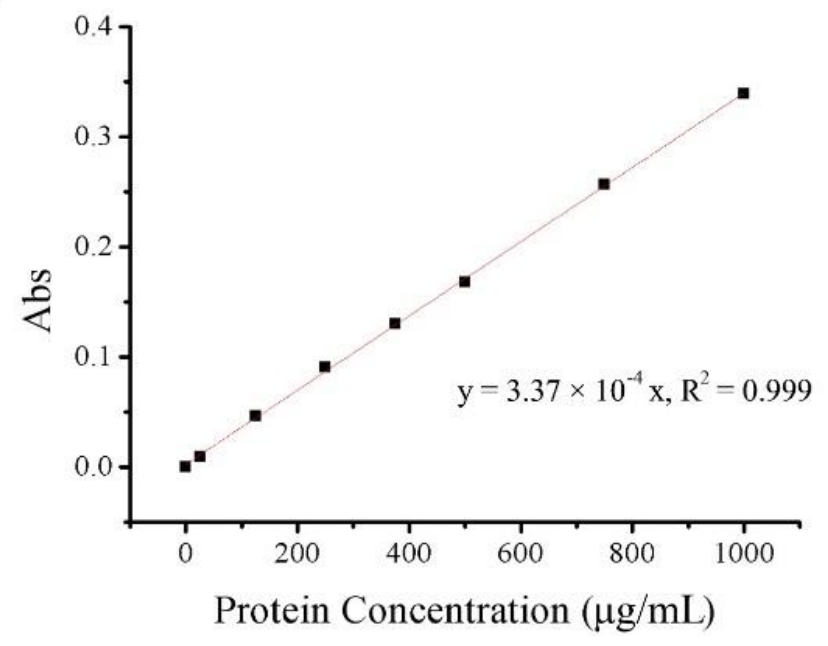

(b)

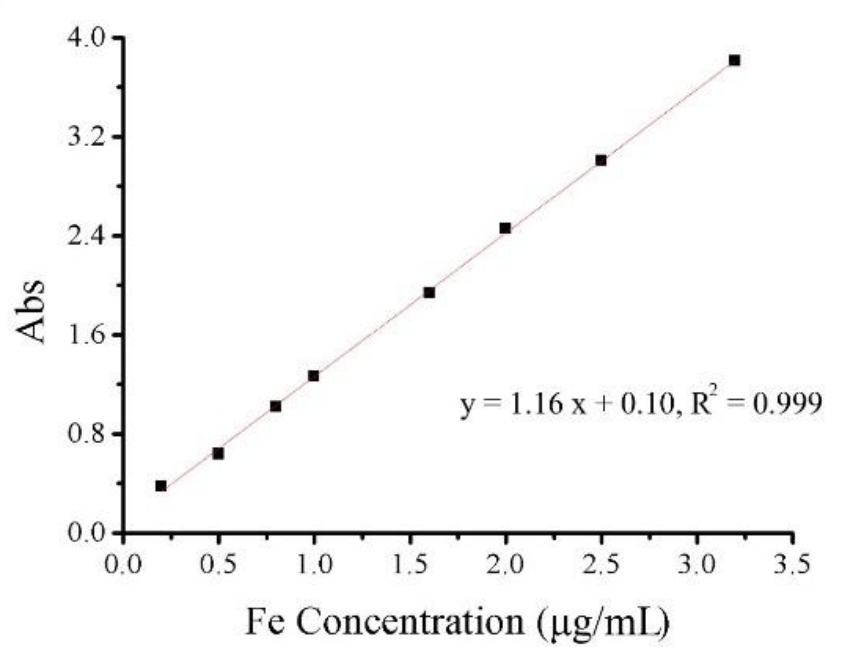

Figure S2. (a) Linear fitting of the $\mathrm{OD}_{562}$-protein concentration curve using BCA assay with BSA as reference. (b) Linear fitting of the $\mathrm{OD}_{562}-\mathrm{Fe}$ concentration curve with $\left(\mathrm{NH}_{4}\right)_{2} \mathrm{Fe}\left(\mathrm{SO}_{4}\right)_{2}$ as reference.

Table S1. The $n$-octanol/water partition coefficients $(\log P)$ of ruthenium complexes with $\mathrm{Cl}$ or $\mathrm{PF}_{6}$ as counterion.

\begin{tabular}{cc}
\hline Ruthenium Complex & $\log P$ \\
\hline $\mathbf{R u 1 C l}$ & -3.51 \\
$\mathbf{R u 1}\left(\mathrm{PF}_{6}\right)_{2}$ & -2.45 \\
$\mathbf{R u} 2 \mathrm{Cl}_{2}$ & -2.53 \\
$\mathbf{R u}_{2}\left(\mathrm{PF}_{6}\right)_{2}$ & -1.76 \\
$\mathbf{R u 3 C l}_{2}$ & -2.90 \\
$\mathbf{R u 3}_{2}\left(\mathrm{PF}_{6}\right)_{2}$ & -1.39 \\
\hline
\end{tabular}


(a)

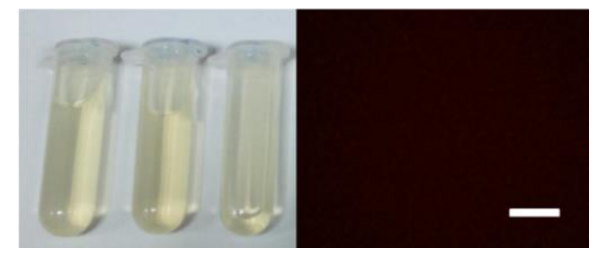

(b)

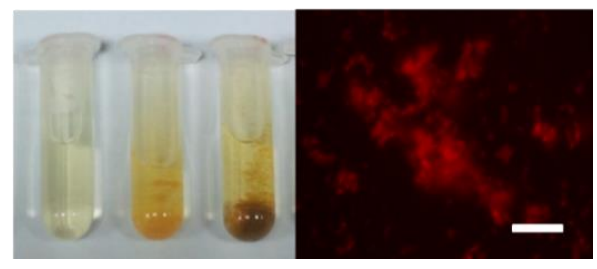

(c)

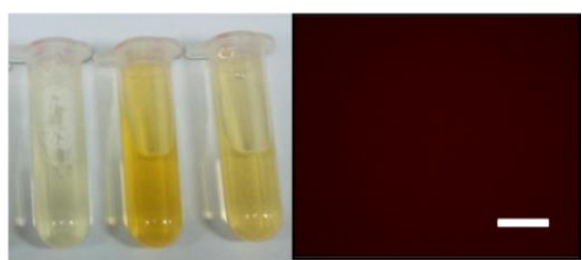

Figure S3. Protein solution derived from (a) Tris $\mathrm{HCl}$ dialysis at the feed molar ratio of 1:100 (ferritin cages: $\mathrm{Ru}$ complexes), (b) Tris $\mathrm{HCl}$ dialysis at the feed molar ratio of 1:200 and (c) acetonitrile-Tris $\mathrm{HCl}$ dialysis at the feed molar ratio of 1:200. Ru-NP solution (left: Ru1-NP, Ru2-NP, and Ru3-NP) and Ru3-NP observed on an inverted fluorescence microscope (Scale bar $=50 \mu \mathrm{m})$. 

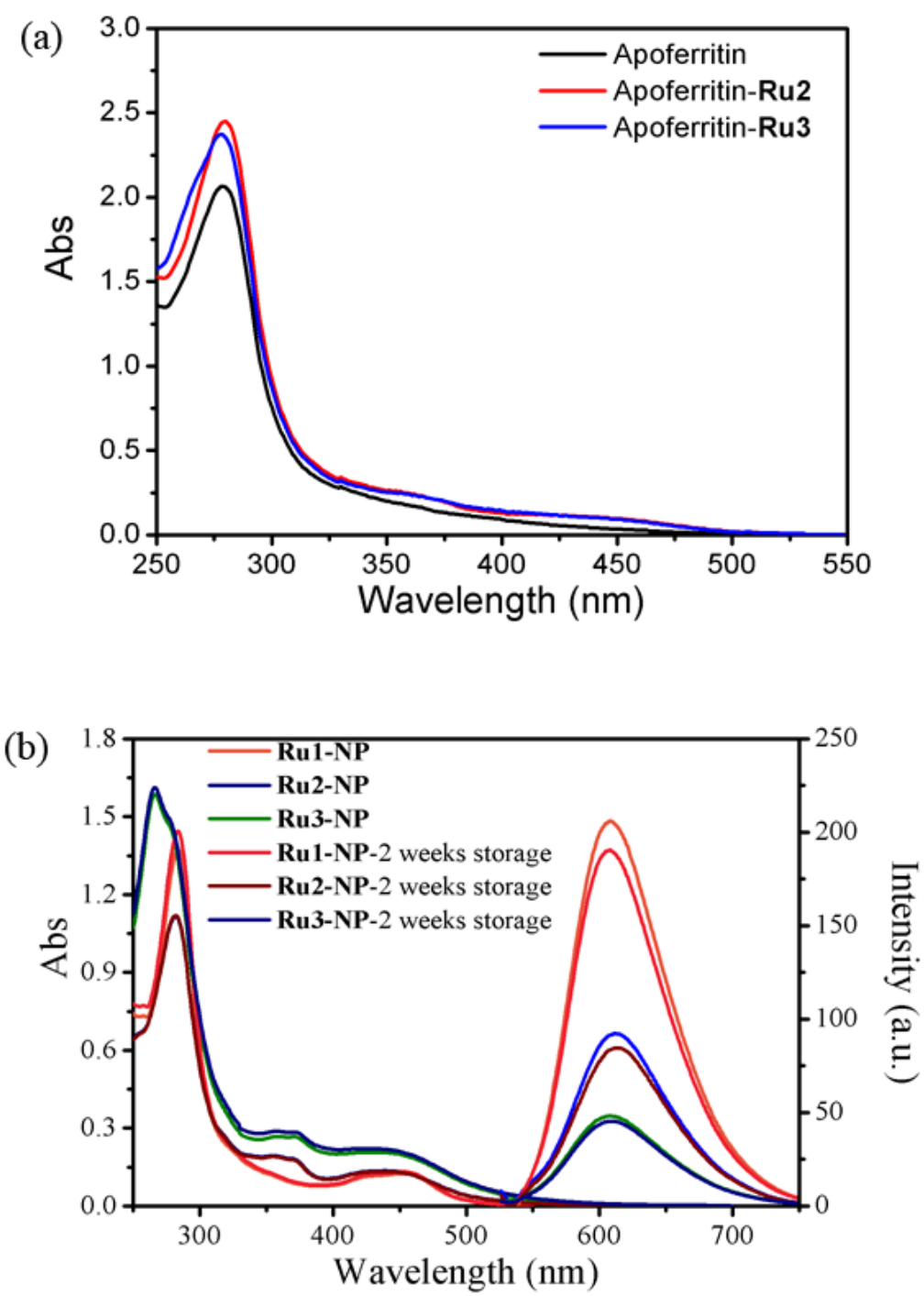

Figure S4. (a) UV-Vis spectra of apoferritin, apoferritin-Ru2 and apoferritin-Ru3. Apoferritin-Ru species were the mix of apoferritin with $\mathbf{R u 2}$ or $\mathbf{R u 3}$ without dissociation-reassociation process, then treated following the procedure of Ru encapsulation. (b) Changes of UV-Vis and fluorescence emission spectra of Ru-NPs before and after 2-week storage at refrigerator. 


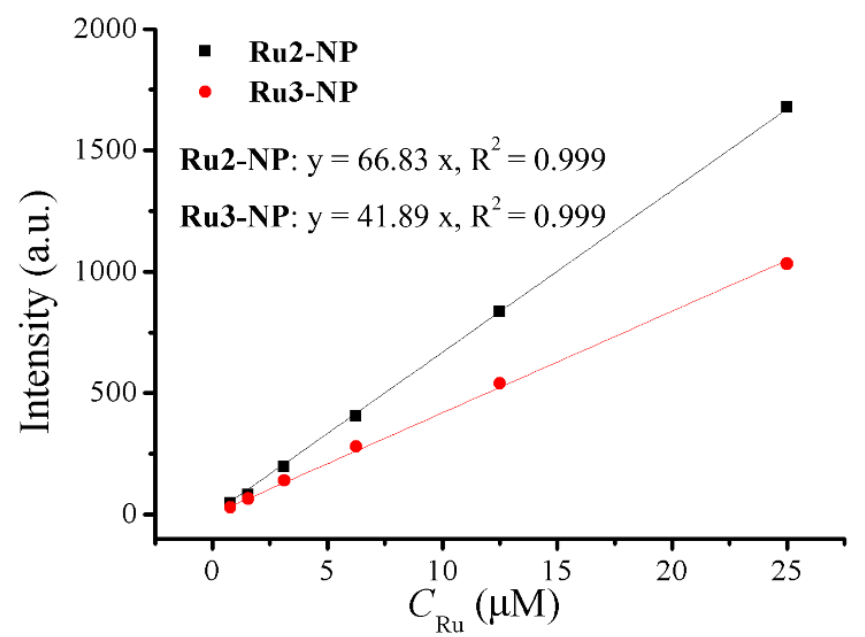

Figure S5. Linear fitting of the $I-C_{\mathrm{Ru}}$ curves. 

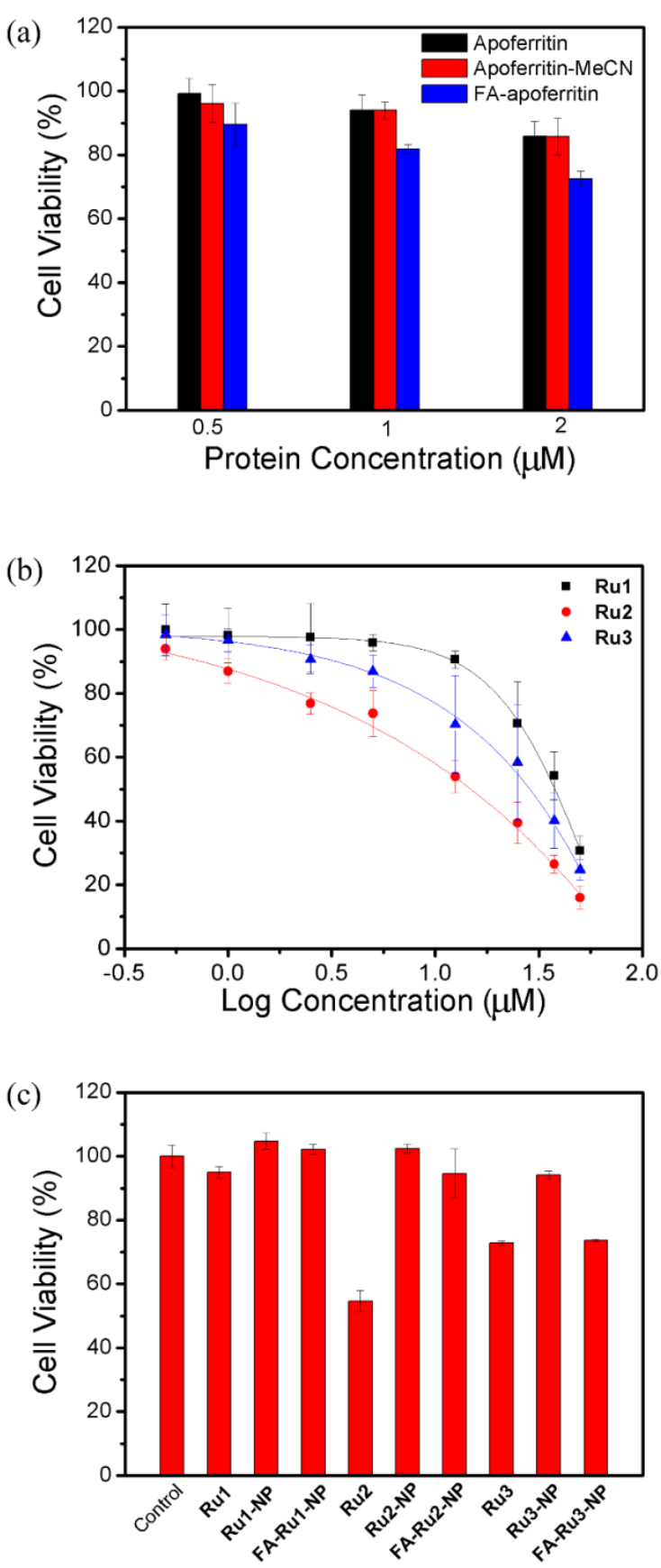

Figure S6. MTT assay results. (a) Plot of cell viability as a function of protein concentration. (b)

Plot of cell viability as a function of the logarithm of Ru concentration. (c) Cell viability versus various $\mathrm{Ru}$ species. 


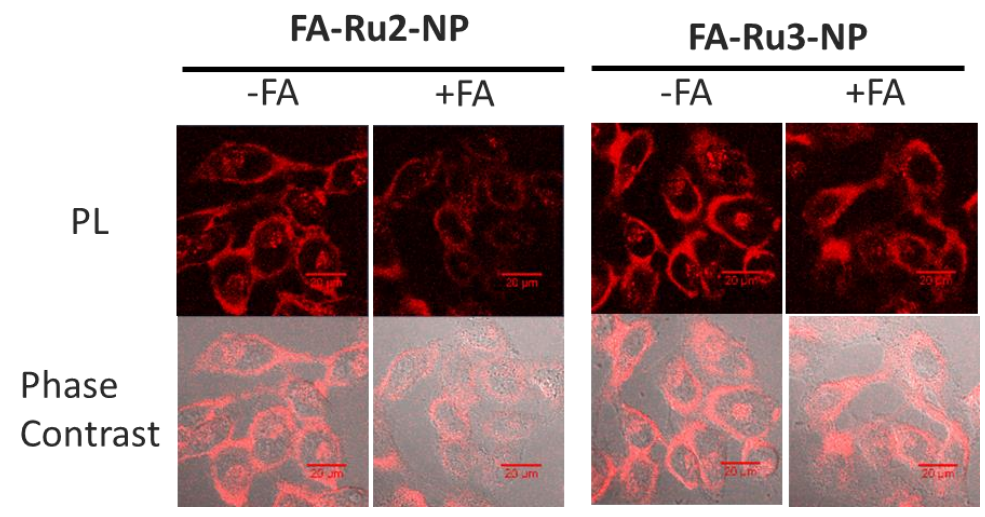

Figure S7. Confocal fluorescent microscopy images of MCF-7 cells (Scale bar $=20 \mu \mathrm{m})$. The cells were pretreated with folic acid (+FA) or devoid of FA treatment (-FA) prior to incubation with Ru species.

\section{Reference}

(1) Hartshorn, R. M. and Barton, J. K. Novel Dipyridophenazine Complexes of Ruthenium(II): Exploring Luminescent Reporters of DNA. J. Am. Chem. Soc. 1992, 114, 5919-5925.

(2) Anil K. G., Marshall F., Jeffrey M. W., Sebastian P., Constantin C. C., F. Richard K. and J. Grant C.. Mononuclear Polypyridylruthenium(II) Complexes with High Membrane Permeability in Gram-Negative Bacteria-in particular Pseudomonas aeruginosa. Chem. Eur. J. 2015, 21, $10472-10481$.

(3) Funk, F.; Lenders, J. P.; Crichton, R. R.; Schneider, W. Reductive Mobilisation of Ferritin Iron. Eur. J. Biochem. 1985, 152, 167-172.

(4) Fish, W. W. Rapid Colorimetric for the Quantitation of Complexed Iron in Biological Samples. Methods Enzymol. 1988, 158, 357-364.

(5) McKinley, A.W.; Lincoln, P. and Tuite, E. M. Sensitivity of $\left[\mathrm{Ru}(\mathrm{phen})_{2} \mathrm{dppz}\right]^{2+}$ Light Switch Emission to Ionic Strength, Temperature, and DNA Sequence and Conformation. Dalton Trans. 2013, 42, 4081-4090. 
(6) Nakamaru, K. Synthesis, Luminescence Quantum Yields, and Lifetimes of Trischelated Ruthenium(II) Mixed-Ligand Complexes Including 3,3'-Dimethyl-2,2'-Bipyridyl. Bull. Chem. Soc. Jpn. 1982, 55, 2697-2705.

(7) Latouche, C.; Lanoe, P. H.; Williams, J.A.; Guerchais, V.; Boucekkine, A. and Fillaut, J. L. Switching of Excited States in Cyclometalated Platinum Complexes Incorporating Pyridyl-acetylide Ligands (Pt-CEC-py): a Combined Experimental and Theoretical Study. New J. Chem. 2011, 35, 2196-2202.

(8) Lee, R. J. and Low, P. S. Delivery of Liposomes into Cultured $\kappa B$ Cells via Folate Receptor-Mediated Endocytosis. J. Biol. Chem. 1994, 269, 3198-3204. 